\title{
CHEMICAL CROSS-LINKING OF CHITOSAN/POLYVINYL ALCOHOL ELECTROSPUN NANOFIBERS
}

\author{
KEMIJSKO ZAMREŽENJE ELEKTRO SPREDENIH NANOVLAKEN \\ IZ HITOSAN/POLIVINIL ALKOHOLA
}

\author{
Sara Pouranvari ${ }^{1}$, Firouz Ebrahimi ${ }^{2}$, Gholamreza Javadi ${ }^{1}$, Bozorgmehr Maddah ${ }^{3}$ \\ ${ }^{1}$ Islamic Azad University, Department of Biology, Science and Research Branch, Tehran, Iran \\ 2IHU, Basic Sciences Faculty, Biology Research Center, Tehran, Iran \\ ${ }^{3}$ IHU, Basic Sciences Faculty, Department of Chemistry, Tehran, Iran \\ febrhimi@ihu.ac.ir
}

Prejem rokopisa - received: 2015-04-17; sprejem za objavo - accepted for publication: 2015-07-08

doi: $10.17222 /$ mit. 2015.083

\begin{abstract}
Electrospun nanofibrous scaffolds have great potential for many biomedical applications. In the present study, we fabricated and characterized chitosan/polyvinyl alcohol (Chi/PVA) nanofibrous scaffolds through electrospinning. Cross-linking was performed using chemically with $5 \%$ glutaraldehyde vapor. The morphology and chemical banding of the electrospun nanofibers before and after cross-linking were evaluated using scanning electron microscopy (SEM) and Attenuated Total ReflectanceFourier Transform InfraRed (ATR-FTIR) spectroscopy. SEM micrographs and FTIR spectra showed that the cross-linking process was accomplished successfully. With the biocompatibility and non-toxicity of chitosan and PVA, it is expected that this electrospun nanofibrous scaffold could be an excellent candidate for biomedical applications.

Keywords: electrospinning, chitosan, polyvinyl alcohol, cross-linking
\end{abstract}

Mreže iz elektro spredenih nanovlaken imajo velik potencial za uporabo v biomedicini. V študiji smo izdelali in karakterizirali nanovlaknasto mrežo, izdelano z elektro predenjem nanovlaken iz hitosan/polivinil alkohola (Chi/PVA). Zamreženje je bilo izdelano s pomočjo kemijske metode s $5 \%$ glutaraldehidne pare. Morfologija in kemijsko povezovanje elektro predenih nanovlaken, pred in po zamreženju, sta bila ocenjena z uporabo vrstičnega elektronskega mikroskopa (SEM) in z metodo z oslabljenim odbojem infrardeče spektroskopije s Fourierjevo transformacijo (ATR-FTIR). SEM-posnetki in FTIR-spekter sta pokazala, da je bil postopek zamreženja uspešno dosežen. Glede na biokompatibilnost in netoksičnost hitosana in PVA se pričakuje, da bodo mreže iz elektro spredenih nanovlaken odličen element za uporabo v biomedicini.

Ključne besede: elektro-predenje, hitosan, polivinil alkohol, zamreženje

\section{INTRODUCTION}

Electrospinning is a simple, versatile and cost effective method for forming non-woven fibrous scaffolds. Technically, the electrospinning process uses a high voltage source to draw a polymer fluid into fine fibers which are deposited on a collector. ${ }^{1}$ In recent years, the use of electrospun nanofibers for biomedical applications such as tissue engineering ${ }^{2}$, wound dressing ${ }^{3}$, protein immobilization ${ }^{4}$, materials for artificial blood vessels ${ }^{5}$, barriers for the prevention of induced adhesion after operation $^{6}$, and vehicles for drug or gene delivery ${ }^{7}$ has attracted a great deal of attention from scientists. Electrospinning of synthetic and natural polymers has been reported for collagen ${ }^{8}$, gelatin ${ }^{9}$, silk fibroin ${ }^{10}$, polyglycolide $(\mathrm{PGA})^{11}$, polylactide (PLA) ${ }^{12}$ and poly $(\varepsilon$-caprolactone) (PCL) $)^{13}$, polyurethane ${ }^{14}$, poly(vinylalcohol $)^{15}$, $\mathrm{PEO}^{16}$, polydioxanone ${ }^{17}$, and polyphosphazene derivatives. ${ }^{18}$ Furthermore, the blending of two or more polymers and copolymerization are effective methods for the preparation of composites with new and desirable properties. Obviously, by adjusting the ratio of the components, structure and morphology of the nanofibers and the biological properties of the electrospun scaffolds can be tailored to the desired traits and functions. ${ }^{1}$ For example PLGA ${ }^{7}, \mathrm{P}(\mathrm{LA}-\mathrm{CL})$ copolymers, ${ }^{19}$ and mixtures of collagen with elastin, ${ }^{20}$ gelatin with PCL, ${ }^{9}$ chitosan with poly(ethylene oxide) $(\mathrm{PEO})^{21}$ and chitosan with $\mathrm{PVA}^{22}$ have all been utilized to fabricate electrospun nanofibrous scaffolds for biomedical applications.

In biomedical applications, after electrospinning, different cross-linking methods can be uses to provide stabilization against aqueous environments for those scaffolds produced from aqueous soluble polymers (For example: PVA).

In the present study, electrospinning of a chitosan and PVA blend was performed. Chitosan was selected due to its cytocompatibility, biocompatibility, biodegradability and antibacterial activity. ${ }^{23}$ PVA was used due to its biocompatibility, biodegradability, non-toxicity, chemical resistance, and good fiber-forming properties. ${ }^{24}$

\section{MATERIALS AND METHODS}

\subsection{Materials}

PVA (average molecular weight of 70000-100000 $\mathrm{g} / \mathrm{mol}$ ) and chitosan (medium molecular weight) were purchased from Sigma-Aldrich (St. Louis, MO). Acetic 
acid and glutaraldehyde were obtained from Merck (Germany).

\subsection{Preparation of the solutions}

Chitosan and PVA were dissolved in $50 \%$ aqueous solution of acetic acid at a concentration of $2 \%$ mass fraction and $15 \%$ mass fraction, respectively. The chitosan solution and PVA solution were mixed together with a weight ratio of 40/60 (Chi/PVA) under magnetic stirring at $60{ }^{\circ} \mathrm{C}$.

\subsection{Preparation of nanofibrous membranes}

The optimal conditions for the electrospinning were as follows: $25 \mathrm{kV}$ applied voltage, $15 \mathrm{~cm}$ tip-to-collector distance, and $1 \mathrm{ml} / \mathrm{h}$ flow rate. Moreover, a $5 \mathrm{ml}$ syringe with a 21 gauge stainless-steel needle was used for the delivery of the polymer solution via a syringe pump.

\subsection{Crosslinking of nanofibrous membranes}

Samples were exposed to the $5 \%$ glutaraldehyde (GA) vapor at room temperature for $48 \mathrm{~h}$ for cross-linking to stabilize them against aqueous media solubility and enhance their biomechanical properties biomedical applications. After crosslinking, the samples were carefully washed several times with $2 \%$ glycine for the inactivation and removal of the GA. ${ }^{25}$

\subsection{Characterization of nanofibrous membranes}

The morphology and microstructure of the electrospun nanofibers before and after cross-linking were determined by Scanning Electron Microscopy (SEM). The average diameter of fibers were calculated using the ImageJ (US National Institute of Health, Bethesda, MD) image analysis program by analyzing at least 50 fibers in ten SEM micrographs. The chemical structures of the chitosan and PVA powders and Chi/PVA nanofiber membranes before and after cross-linking were investigated by Attenuated Total Reflectance-Fourier Transform InfraRed (ATR-FTIR) spectroscopy (Bruker Tensor 27, USA). FTIR spectra were obtained in the $4000 \mathrm{~cm}^{-1}$ to $400 \mathrm{~cm}^{-1}$ wavenumber range, with the data analyzed using OPUS software.

\section{RESULTS AND DISCUSSION}

\subsection{Morphology of the nanofibrous scaffold}

SEM images of Chi/PVA nanofibers before and after GA cross-linking are shown in Figure 1. As seen in Figure 1a, relatively fine, continuous, uniform fiberstructures (no bead), and randomly oriented fibers were obtained. The average fiber diameter was found to be $180 \pm 2.28 \mathrm{~nm}$. In accordance with the relatively fine fibers fabricated, it is expected that a suitable porosity exists for biomedical applications.
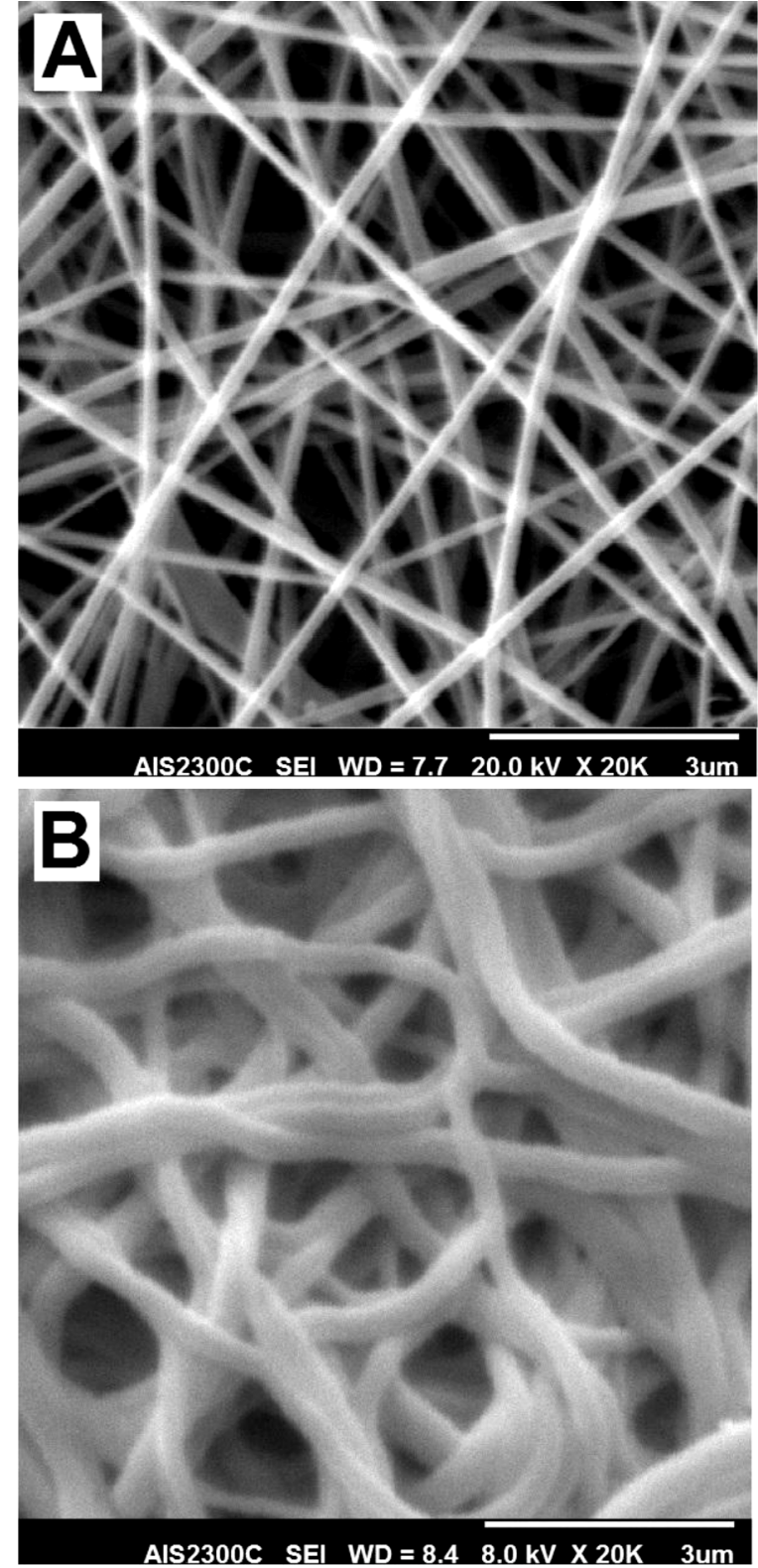

Figure 1: SEM micrographs of electrospun Chi/PVA nanofibers, after $48 \mathrm{~h}$ immersion in water at $37^{\circ} \mathrm{C}$ : a) before GA cross-linking and b) after GA cross-linking

Slika 1: SEM posnetek elektro spredenih Chi/PVA nanovlaken, po $48 \mathrm{~h}$ namakanja v vodi s $37^{\circ} \mathrm{C}$ : a) pred GA zamreženjem in b) po GA zamreženju

\subsection{Crosslinking of nanofibrous scaffold}

The SEM micrographs of the cross-linked nanofibers after immersion in water (at least $48 \mathrm{~h}$ ) are shown in Figure 1b. As PVA is a water-soluble polymer, crosslinking should be performed for the use of Chi/PVA nanofibers in biomedical applications. Several studies have been reported on GA cross-linking for medical application. For example, Jafari et al. used a saturated vapor of a $25 \% \mathrm{GA}$ aqueous solution for cross-linking of chitosan-gelatin electrospun nanofibers. ${ }^{26}$ In another study cross-linking of electrospun water-soluble carbo- 
A
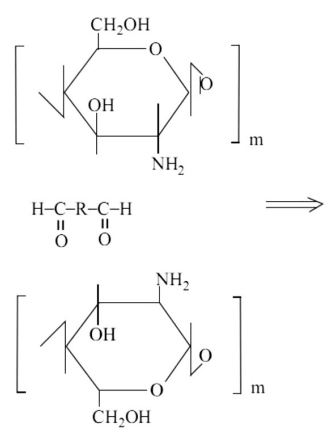

B
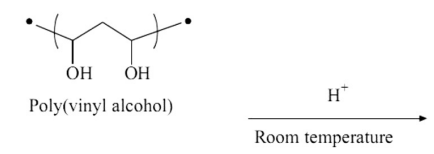

$\mathrm{OHCCH}_{2} \mathrm{CH}_{2} \mathrm{CH}_{2} \mathrm{CHO}$
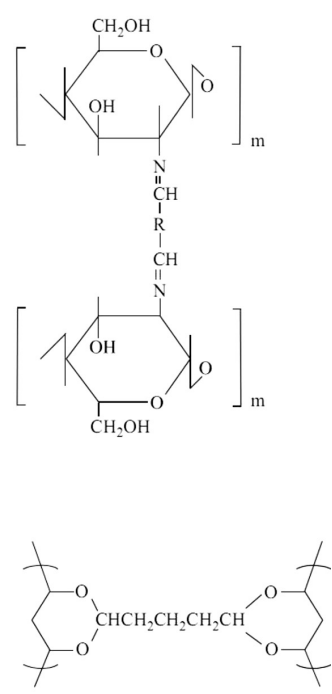

Figure 2: Schematic representation of cross-linking reaction of chitosan with GA and cross-linking reaction of PVA with GA 1,2

Slika 2: Shematski prikaz reakcije zamreženja hitosana z GA in reakcije zamreženja PVA z GA ${ }^{1,2}$

xyethyl chitosan/poly (vinyl alcohol) nanofibrous membrane towards wound dressings for skin regeneration was performed using a GA vapor. ${ }^{27}$ Unlike the previous work, in the present study, the cross-linking was performed using a lower concentration of GA vapor (5\%). Despite using this low concentration, it was proved that the fabricated membranes' structure is stable in an aqueous solution. Moreover, according to the SEM micrographs shown in Figure 1, the porous structure of the fabricated membranes remained intact implying that they are insoluble in water. The cross-linking mechanism of chitosan and PVA with GA is shown in Figure 2. ${ }^{28,29}$

\subsection{ATR-FTIR analysis}

FTIR spectra were taken of the electrospun nanofibers before and after cross-linking, to assess their chemical groups. The FTIR spectrum of the Chi/PVA blended nanofibers before cross-linking, is shown in Figure 3. The two peaks at $1423 \mathrm{~cm}^{-1}$ and $1565 \mathrm{~cm}^{-1}$ arise fromcarboxylic acid and symmetric deformation of ${ }^{-} \mathrm{NH}^{+}$groups due to ionization of primary amino groups in the acidic medium, respectively. The peak at $1703 \mathrm{~cm}^{-1}$ is attributed to the carboxylic acid dimer. ${ }^{22}$ In this study, this peak is due to the acetic acid utilized for dissolving the chitosan. The peak located at $1244 \mathrm{~cm}^{-1}$ is related to the $\mathrm{C}-\mathrm{O}$ of the $\mathrm{CH} 2 \mathrm{OH}$ chitosan group forming a hydrogen bond with the $\mathrm{OH}$ of PVA, confirming the fabrication of Chi/PVA blend nanofibers. ${ }^{30}$ The FTIR spectra of the Chi/PVA blended nanofibers before cross-linking is given in Figure 3. Chemical crosslinking of the chitosan/PVA is verified by the peak located at $1586 \mathrm{~cm}^{-1}$ attributed to the $\mathrm{C}-\mathrm{N}$ band. All chitosan-derived blends cross-linked with GA, have shown the presence of the imine $(\mathrm{C}=\mathrm{N})$ band. The imine band was formed by the

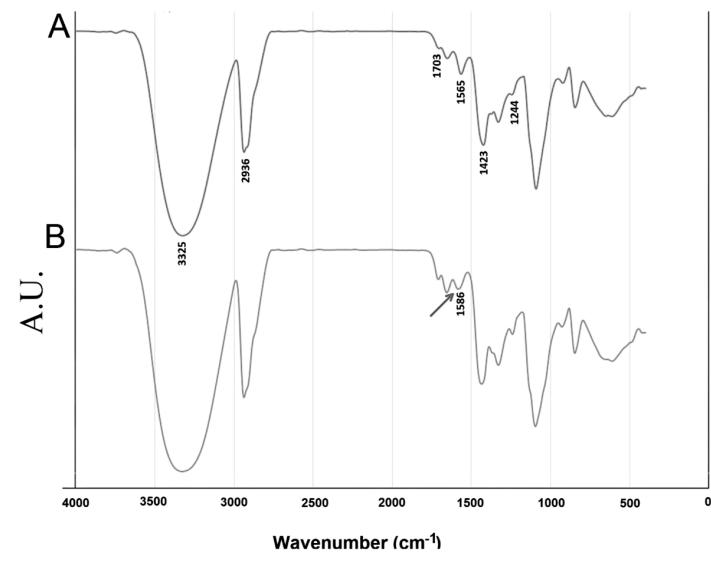

Figure 3: ATR-FTIR analysis of Chi/PVA electrospun samples: a) before chemical electrospinning and $b$ ) after electrospinning

Slika 3: ATR-FTIR analiza elektropredenih Chi/PVA vzorcev: a) pred kemijskim elektropredenjem in b) po elektropredenju

nucleophilic reaction of the amine from chitosan with the aldehyde group of GA. ${ }^{31}$ Due to imine band instability with temperature and $\mathrm{pH}$, this group can transform to a C-N group. ${ }^{32}$

\section{CONCLUSION}

In this work, nanofibrous Chi/PVA was fabricated via electrospinning and stabilized by chemical cross-linking using $5 \% \mathrm{GA}$. The porous structure of the electrospun scaffolds, antimicrobial properties of the chitosan and chemical resistant traits of PVA, make our fabricated electrospun scaffold an excellent candidate for biomedical applications. However, in vitro and in vivo experiments for evaluation of the biocompatibility of these Chi/PVA nanofiberous membranes is necessary.

\section{REFERENCES}

${ }^{1}$ D. Liang, B. S. Hsiao, B. Chu, Functional electrospun nanofibrous scaffolds for biomedical applications, Advanced drug delivery reviews, 59 (2007) 14, 1392-1412, doi:10.1016/j.addr.2007.04.021

${ }^{2}$ F.Yang, R. Murugan, S. Wang, S. Ramakrishna, Electrospinning of nano/micro scale poly(L-lactic acid) aligned fibers and their potential in neural tissue engineering, Biomaterials, 26 (2005) 15, 2603-2610, doi:10.1016/j.biomaterials.2004.06.051

${ }^{3}$ M. Gumusderelioglu, S. Dalkiranoglu, R. S. Aydin, S. Cakmak, A novel dermal substitute based on biofunctionalized electrospun PCL nanofibrous matrix, Journal of biomedical materials research Part A, 98 (2011) 3, 461-472, doi:10.1002/jbm.a.33143

${ }^{4} \mathrm{~L}$. Wu, X. Yuan, J. Sheng, Immobilization of cellulase in nanofibrous PVA membranes by electrospinning, Journal of Membrane Science, 250 (2005) 1-2, 167-173, doi:10.1016/j.memsci.2004.10.024

${ }^{5}$ S. A. Sell, M. J. McClure, K. Garg, P. S. Wolfe, G. L. Bowlin, Electrospinning of collagen/biopolymers for regenerative medicine and cardiovascular tissue engineering, Advanced drug delivery reviews, 61 (2009) 12, 1007-1019, doi:10.1016/j.addr.2009.07.012

${ }^{6}$ Y. Wang, Y. L. Hsieh, Enzyme immobilization to ultra-fine cellulose fibers via amphiphilic polyethylene glycol spacers, Journal of Polymer Science Part A: Polymer Chemistry, 42 (2004) 17, 4289-4299, doi:10.1002/pola.20271 


\section{S. POURANVARI et al.: CHEMICAL CROSS-LINKING OF CHITOSAN/POLYVINYL ALCOHOL ...}

${ }^{7}$ D. S. Katti, K. W. Robinson, F. K. Ko, C. T. Laurencin, Bioresorbable nanofiber-based systems for wound healing and drug delivery: optimization of fabrication parameters, Journal of biomedical materials research Part B, Applied biomaterials, 70 (2004) 2, 286-296, doi:10.1002/jbm.b.30041

${ }^{8}$ K. J.Shields, M. J. Beckman, G. L. Bowlin, J. S. Wayne, Mechanical properties and cellular proliferation of electrospun collagen type II, Tissue engineering, 10 (2004) 9, 1510-1517, doi:10.1089/ 1076327042500373

${ }^{9}$ Y. Zhang, H. Ouyang, C. T. Lim, S. Ramakrishna, Z. M. Huang, Electrospinning of gelatin fibers and gelatin/PCL composite fibrous scaffolds, Journal of biomedical materials research Part B, Applied biomaterials, 72 (2005) 1, 156-165, doi:10.1002/jbm.b.30128

${ }^{10}$ B. M. Min,L. Jeong, Y. S. Nam, J. M. Kim, J. Y. Kim, W. H. Park, Formation of silk fibroin matrices with different texture and its cellular response to normal human keratinocytes, International journal of biological macromolecules,34 (2004) 5, 281-288, doi:10.1016/ j.ijbiomac.2004.08.004

${ }^{11}$ E. D. Boland, T. A. Telemeco, D. G. Simpson, G. E. Wnek, G. L. Bowlin, Utilizing acid pretreatment and electrospinning to improve biocompatibility of poly(glycolic acid) for tissue engineering, Journal of biomedical materials research Part B, Applied biomaterials, 71 (2004) 1, 144-152, doi:10.1002/jbm.b.30105

${ }^{12}$ F. Yang, C. Y. Xu, M. Kotaki, S. Wang, S. Ramakrishna, Characterization of neural stem cells on electrospun poly(L-lactic acid) nanofibrous scaffold, Journal of biomaterials science Polymer edition, 15 (2004) 12, 1483-1497, doi:10.1163/1568562042459733

${ }^{13}$ E. P. S. Tan, S. Y. Ng, C. T. Lim, Tensile testing of a single ultrafine polymeric fiber, Biomaterials, 26 (2005) 13, 1453-1456, doi:10.1016/j.biomaterials.2004.05.021

${ }^{14}$ G. Tetteh, A. S. Khan, R. M. Delaine-Smith, G. C. Reilly, I. U. Rehman, Electrospun polyurethane/hydroxyapatite bioactive Scaffolds for bone tissue engineering: The role of solvent and hydroxyapatite particles, Journal of the Mechanical Behavior of Biomedical Materials, 39 (2014), 95-110, doi:10.1016/j.jmbbm.2014.06.019

${ }^{15}$ L. Yao, T. W. Haas, A. Guiseppi-Elie, G. L. Bowlin, D. G. Simpson, G. E. Wnek, Electrospinning and Stabilization of Fully Hydrolyzed Poly(Vinyl Alcohol) Fibers, Chemistry of Materials, 15 (2003) 9, 1860-1864, doi:10.1021/cm0210795

${ }^{16}$ W. K. Son, J. H. Youk, T. S. Lee, W. H. Park, The effects of solution properties and polyelectrolyte on electrospinning of ultrafine poly(ethylene oxide) fibers, Polymer, 45 (2004) 9, 2959-2966, doi:10.1016/j.polymer.2004.03.006

${ }^{17}$ E. D. Boland, B. D. Coleman, C. P. Barnes, D. G.Simpson, G. E. Wnek, G. L. Bowlin, Electrospinning polydioxanone for biomedical applications, Acta biomaterialia, 1 (2005) 1, 115-123, doi:10.1016/ j.actbio.2004.09.003

${ }^{18}$ L. S. Nair, S. Bhattacharyya, J. D. Bender, Y. E. Greish, P. W. Brown, H. R. Allcock et al., Fabrication and optimization of methylphenoxy substituted polyphosphazene nanofibers for biomedical applications, Biomacromolecules, 5 (2004) 6, 2212-2220, doi:10.1021/bm049759j

${ }^{19}$ I. K. Kwon, S. Kidoaki, T. Matsuda, Electrospun nano- to microfiber fabrics made of biodegradable copolyesters: structural characteris- tics, mechanical properties and cell adhesion potential, Biomaterials, 26 (2005) 18, 3929-3939, doi:10.1016/j.biomaterials.2004.10.007

${ }^{20}$ E. D. Boland, J. A. Matthews, K. J. Pawlowski, D. G. Simpson, G. E. Wnek, G. L. Bowlin, Electrospinning collagen and elastin: preliminary vascular tissue engineering, Frontiers in bioscience : a journal and virtual library, 9 (2004) 1-3, 1422-1432, doi:10.2741/1313

${ }^{21}$ B. Duan, C. Dong, X. Yuan, K. Yao, Electrospinning of chitosan solutions in acetic acid with poly(ethylene oxide), Journal of biomaterials science Polymer edition, 15 (2004) 6, 797-811, doi:10.1163/ 156856204774196171

${ }^{22}$ S. N. Alhosseini, F. Moztarzadeh, M. Mozafari, S. Asgari, M. Dodel, A. Samadikuchaksaraei et al., Synthesis and characterization of electrospun polyvinyl alcohol nanofibrous scaffolds modified by blending with chitosan for neural tissue engineering, International journal of nanomedicine, 7 (2012), 25-34, doi:10.2147/ijn.s25376

${ }^{23}$ E. Khor, L. Y. Lim, Implantable applications of chitin and chitosan, Biomaterials, 24 (2003) 13, 2339-2349, doi:10.1016/s0142-9612 (03)00026-7

${ }^{24}$ I. Gibas, H. Janik, Review: synthetic polymer hydrogels for biomedical applications, Chemistry Chemical technol, 4 (2010) 4, 297-304

${ }^{25}$ S. S.Block, Disinfection, Sterilization and Preservation, Lea \& Febiger, Philadelphia 1991

${ }^{26}$ J. Jafari, S. H. Emami, A. Samadikuchaksaraei, M. A. Bahar, F. Gorjipour, Electrospun chitosan-gelatin nanofiberous scaffold: fabrication and in vitro evaluation, Bio-medical materials and engineering, 21 (2011) 2, 99-112, doi:10.3233/BME-2011-0660

${ }^{27}$ Y. Zhou, D. Yang, X. Chen, Q. Xu, F. Lu, J. Nie, Electrospun watersoluble carboxyethyl chitosan/poly(vinyl alcohol) nanofibrous membrane as potential wound dressing for skin regeneration, Biomacromolecules, 9 (2008) 1, 349-54, doi:10.1021/bm7009015

${ }^{28}$ S. Nakatsuka, A. L. Andrady, Permeability of vitamin B-12 in chitosan membranes. Effect of crosslinking and blending with poly(vinyl alcohol) on permeability, Journal of Applied Polymer Science, 44 (1992) 1, 17-28, doi:10.1002/app.1992.070440103

${ }^{29}$ J. Jegal, K. H. Lee, Nanofiltration membranes based on poly(vinyl alcohol) and ionic polymers, Journal of Applied Polymer Science, 72 (1999), 1755-62, doi:10.1002/(sici)1097-4628(19990624)72:13 $<1755$ ::aid-app11>3.0.co;2-r

${ }^{30}$ A. Gholipour, K. S. H. Bahrami, M. Nouri M, Chitosan-poly (vinyl alcohol) blend nanofibers: morphology, biological and antimicrobial properties, e-Polymers, 9 (2009) 1, 1580-1591, doi:10.1515/epoly. 2009.9.1.1580

${ }^{31}$ U. Parida, A. Nayak, B. Binhani, P. Nayak, Synthesis and Characterization of Chitosan-Polyvinyl Alcohol Blended with Cloisite 30B for Controlled Release of the Anticancer Drug Curcumin, Journal of Biomaterials and Nanobiotechnology, 2 (2011) 4, 414-425, doi:10.4236/jbnb.2011.24051

${ }^{32}$ T. Wang, M.Turhan, S. Gunasekaran, Selected properties of $\mathrm{pH}-\mathrm{sen}$ sitive, biodegradable chitosan-poly (vinyl alcohol) hydrogel, Polymer International, 53 (2004) 7, 911-918, doi:10.1002/pi.1461 